<단보>

$$
\begin{aligned}
& \text { 개꼬시래기 (Gracilariopsis chorda) 추출물의 } \\
& \text { 장파장자외선 차단효과 및 항산화효과 }
\end{aligned}
$$

\title{
Ultraviolet-A Blocking Effect and Antioxidant Activity of Gracilariopsis chorda Extract
}

\author{
Won-Soon Jung*, Eun-Kyung Park, Sung-Pil Kang ${ }^{1}$, \\ Sang-Hee Park and Mi-Jin Lee \\ ATHENA Co. Ltd., SNU Business Incubator 2-102, Suwon 441-853, Korea \\ ${ }^{1}$ Jeollanamdo Marine Bio Research Institute, Shinan 535-800, Korea
}

This study examined the ultraviolet-A blocking effect and antioxidant activity of Gracilariopsis chorda extract for use as sunscreen agents in cosmetics. The maximum absorbance at ultra violet-A320-330 and transmissivity was 20-80\%. The 1,1-diphenyl-2-picrylhydrazyl (DPPH)radical scavenging activity of Gracilariopsis chorda extract was $68-96 \%$ and increased with the sample concentration. This indicates that Gracilariopsis chorda extract is a promising natural compound that could be useful as a sunscreen. Key words: Gracilariopsis chorda, Antioxidant, UVA blocking, Sunscreen

서 론

자외선은 태양에서 발산되는 $400 \mathrm{~nm}$ 이하의 파장을 가지는 광선으로 장파자외선 (UVA; $320 \sim 400 \mathrm{~nm}$ ), 중파자외선 (UVB; $280 \sim 320 \mathrm{~nm}$ ), 단파자외선 (UVC; $200 \sim 280 \mathrm{~nm}$ )로 나 누어지고 피부에 광생물학적 반응을 일으켜 일광화상, 색소침 착, 광노화, 피부암 등을 일으키며 파장에 따라 다양한 피부손 상을 유발한다 (Lee, 2008). 특히, 장파자외선 (Ultraviolet -A) 은 진피까지 도달하여 즉각적인 색소침착과 홍반, 광독성, 광알레르기반응 및 free radical 생성으로 만성적 광노화를 일 으키며 진피의 탄력섬유와 교원섬유를 변성시킴으로써 피부 의 탄력은 감소시키고 주름, 피부위축 현상을 유발하기 때문 에 자외선 차단제를 이용하여 인체에 대한 직접적인 피해를 최소화 해야 한다 (Lee, 2008). 현재 자외선 차단제는 유기자외 선 흡수제와 무기 자외선 차단제가 많이 사용되고 있으나 무기차단제의 경우 피부에 자극을 일으키고 용해가 어려워 피부에 백탁현상을 일으키고 유기자외선 흡수제인 벤조페논 유도체, 파라아미노안식향산 유도체, 파라메톡시계피산 유도 체, 살리실산 유도체는 사용이 용이하여 많이 사용되고 있으 나 자외선차단제 중 그 양이 증가함에 따라 피부자극이 있어 국가별로 사용량과 사용여부에 대하여 규제하고 있다 (Brown et al., 1986; Cole e, al., 1988; Ward, 1987; Kim et al., 2000; Kim, 2004). 이러한 이유로 플라보이드류, 알카로이드류 같은 성분을 함유하는 식물 중 자외선 흡수효과를 가짐으로 유기자 외선흡수제의 사용량을 줄이는 자외선차단 보조제로서 식물 추출성분의 사용 가능성에 대한 연구 (Kim, 2000)를 비롯하여 자외선 차단효과를 가지는 생약추출물을 검색하는 연구가

\footnotetext{
*Corresponding author: athena@athenasc.co.kr
}

진행되고 있으며 $(\mathrm{Kim}, 2004)$ 그 외에도 복분자, 효모유래 셀레늄 펩타이드 등 다양한 천연물로부터 자외선에 대한 보호 물질을 개발하고자 하는 연구가 이루어지고 있다 (Ha et al., 2009; Lee et al., 2009). 따라서 본 연구에서는 이러한 천연유래 자외선차단 소재개발 연구의 일환으로 해조류인 개꼬시래기 (Gracilariopsis chorda)로부터 자외선 흡수제를 개발하고자 하여 본 연구를 수행하였다.

한편, 개꼬시래기 (Gracilariopsis chorda Holmes)는 홍조식 물문 (Rhodophyta), 홍조강 (Rhodophyceae), 꼬시래기목 (Gracilariales), 꼬시래기과 (Gracilariaceae), 꼬시래기속 (Gracilaria)에 속하며 우리나라 남서해안의 조하대에서 발견 되고 있다 (Kim, 2009). 꼬시래기는 주로 한천의 원료로 사용 되고 있으며 (Kim and Koo, 2003) 예로부터 식용으로 사용되 어져 왔다. 하지만 개꼬시래기에 대한 생리활성 연구는 미미 하며 특히, 자외선흡수 및 항산화력에 대한 연구는 이루어진 바 없다.

따라서 본 연구에서는 개꼬시래기로부터 유효물질을 추출 하고 이의 자외선흡수력과 radical 소거능을 확인함으로써 자외 선 차단 화장품에 적용할 수 있는 소재를 개발하고자 하였다.

$$
\text { 재료 및 방법 }
$$

재료

개꼬시래기 (G. chorda)는 2009년 12월 전라남도 진도인근 에서 채집하여 흐르는 증류수에 세척하고 $55^{\circ} \mathrm{C}$ dry oven (VS1202D2, Vison Sientific, Korea)에서 열풍 건조한 후 분쇄하여 $1 \mathrm{~mm}^{2}$ mesh에 통과된 분말을 사용하였다. 


\section{개꼬시래기의 추출}

개꼬시래기 분말 $50 \mathrm{~g}$ 에 $70 \%$ etanol $1 \mathrm{~L}$ 를 가하여 $45^{\circ} \mathrm{C}$ 에서 3 시간씩 3 회 반복추출한 후 $45^{\circ} \mathrm{C}$ 에서 감압 농축하여 추출물을 얻었다. 추출물은 증류수에 현탁시킨 후 동량의 n-butanol로 용매 분획하여 색소를 제거하고 얻어진 물층을 농축하여 동결 건조한 분말을 시험에 사용하였다 (Fig. 1).

\author{
Dried sample $(50 \mathrm{~g})$ \\ $\downarrow 70 \%$ Ethanol \\ Crude extract $(2.5 \mathrm{~g})$ \\ Suspend in water \\ $\downarrow \quad$ Separated by n-butanol
}

n-Butanol fraction - Aqueous fraction

\section{$\downarrow$ Freeze drying}

Final extract $(2 \mathrm{~g})$

Fig. 1. Extract procedure of Gracilariopsis chorda.

\section{추출물의 UV 흡수력 및 투과률 측정}

개꼬시래기 추출물을 $100 \mathrm{ppm}, 200 \mathrm{ppm}, 300 \mathrm{ppm}$ 이 되도록 증류수에 희석 한 후 UV/VIS spectrophotometer (X-ma 3200, Human Co., Korea)를 이용하여 $200 \sim 400 \mathrm{~nm}$ 사이의 UV 파장 에서 흡수스펙트럼을 관찰하였다 (Kim, 2004.). Base line은 증류수로 하였으며 $100 \mathrm{ppm}$ 농도의 합성자외선차단제인 disodium phenyl dibenzimidazole tetrasulfonate (Neohelipan AP, Symrise AG, Germany)를 대조군으로 사용하였다.

\section{추출물의 free radical 소거활성}

개꼬시래기 추출물에 대한 항산화 활성을 측정하기 위하여 DPPH (2,2-diphehyl-pictyl-hydrazyl, Sigma, USA)법을 사용하 였다 (Blois, 1958; Kim et al., 2009). DPPH의 solution은 0.2 $\mathrm{mM}$ 농도에서 사용하였으며 시료는 건조한 추출물을 1 $\mathrm{mg} / \mathrm{mL}, 10 \mathrm{mg} / \mathrm{mL}, 100 \mathrm{mg} / \mathrm{mL}$ 의 농도가 되도록 증류수에 녹여 준비하였으며 대조군인 ascorbic acid는 $1 \mathrm{mg} / \mathrm{mL}$ 의 농도 로 사용하였다. 준비된 시료 $2 \mathrm{~mL}$ 에 DPPH solution $1 \mathrm{~mL}$ 를 가하고 10 초간 vortex mixng한 후 $37^{\circ} \mathrm{C}$ 에서 30 분간 반응시키 고 UV/VIS spectrophotometer ( X-ma 3200, Human Co., Korea) 를 사용하여 $517 \mathrm{~nm}$ 에서 흡광도를 측정하였으며 하기식에 따라 백분율로 나타내었다.

Radical scavenging activity $(\%)=\left(1-\frac{\mathrm{A}-\mathrm{B}}{\mathrm{C}}\right) \times 100$

$\mathrm{A}: 0.2 \mathrm{mM} \mathrm{DPPH}$ 용액에 시료첨가 및 30 분간 반응시킨 후 흡광도

$\mathrm{B}$ : 시료자체 흠광도

$\mathrm{C}: 0.2 \mathrm{mM} \mathrm{DPPH}$ 용액의 흡광도

\section{결과 및 고찰}

\section{개꼬시래기의 UV 스펙트럼}

개꼬시래기 추출물의 흡수 스펙트럼을 보면 장파자외선 영역에서 전체적으로 흡수력을 나타내었으며 농도 의존적으 로 흡수력이 증가하였다 (Fig. 2). 개꼬시래기추출물 100 300 $\mathrm{ppm}$ 의 최대 흡수파장은 $320 \mathrm{~nm}$ 에서 $330 \mathrm{~nm}$ 사이였으며 대조 군인 disodium phenyl dibenzimidazole tetrasulfonate가 $330 \mathrm{~nm}$ 에서 $340 \mathrm{~nm}$ 사이인 것과는 다소 차이가 있었다. 대조군에 대하여 개꼬시래기추출물 $300 \mathrm{ppm}$ 일 때 더 높은 자외선 흡수 력을 나타내어 동일 농도에서 합성자외선차단제보다는 효과 가 낮으나 천연추출물인 것을 감안할 때 매우 우수한 결과로 판단된다. 개꼬시래기추출물의 자외선 투과율은 $300 \mathrm{~nm}$ $350 \mathrm{~nm}$ 사이에서 $20 \sim 80 \%$ 로 개꼬시래기추출물이 자외선을 흡수하여 투과를 억제하는 것으로 나타났다 (Fig. 3).

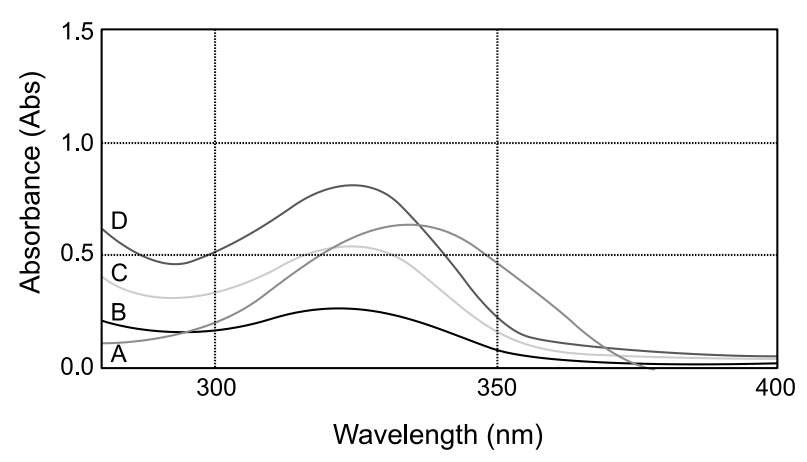

Fig. 2. UV absorbency of Gracilariopsis chorda extract. A; disodium phenyl dibenzimidazole tetrasulfonate $100 \mathrm{ppm}$, B; Gracilariopsis chorda extract 100 ppm, C; Gracilariopsis chorda extract 200 ppm, D; Gracilariopsis chorda extract $300 \mathrm{ppm}$.

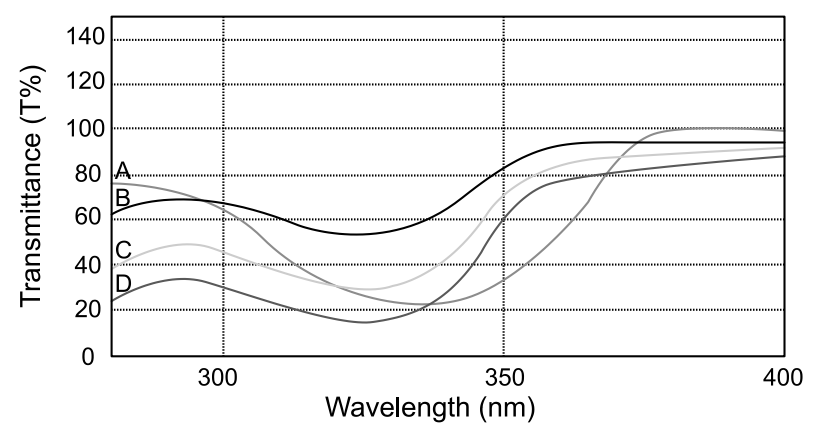

Fig. 3. UV transmissivity of Gracilariopsis chorda extract. A; disodium phenyl dibenzimidazole tetrasulfonate $100 \mathrm{ppm}$, B; Gracilariopsis chorda extract 100 ppm, C; Gracilariopsis chorda extract 200 ppm, D; Gracilariopsis chorda extract $300 \mathrm{ppm}$.

\section{개꼬시래기의 항산화 활성}

전자공여능은 free radical에 대한 전자를 공여하여 산화억 
제력을 나타내는 척도로 $\mathrm{DPPH}$ 에 대한 전자공여능이 크면 높은 항산화활성 및 활성산소를 비롯한 다른 radical에 대한 소거작용을 기대할 수 있다. 본 실험에서 개꼬시래기 추출물 의 농도가 $1 \mathrm{mg} / \mathrm{mL}, 10 \mathrm{mg} / \mathrm{mL}, 100 \mathrm{mg} / \mathrm{mL}$ 일 때 전자공여능은 $68 \%, 88 \%, 96 \%$ 로 매우 높았으며 추출물의 농도가 높아질수록 증가함을 알 수 있었다(Fig. 4). 이는 $100 \mathrm{ppm}$ 의 동일 농도에서 ascorbic acid가 $88 \%$ 의 전자공여능을 나타내고 개꼬시래기 추출물이 $68 \%$ 의 나타내어 ascorbic acid보다 다소 낮은 전자공 여능을 나타내지만 개꼬시래기 추출물이 단순 추출물임을 고려하면 효과적인 전자공여능을 가지는 것으로 판단된다. 이는 자외선에 의해 생성되는 free radical을 제거할 수 있을 것으로 사료된다.

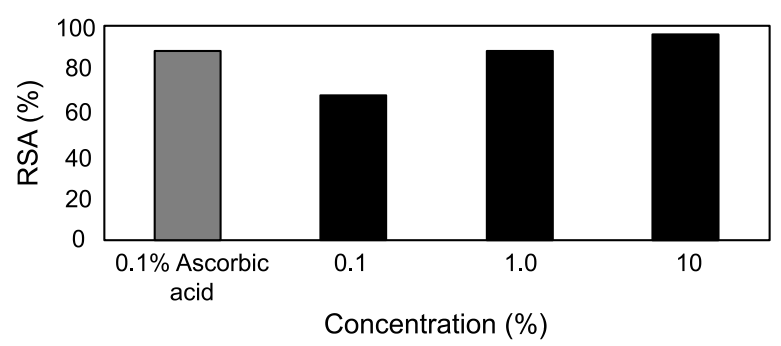

Fig. 4. DPPH free radical scavenging activity (RSA) of Gracilariopsis chorda extract.

$$
\text { 사 사 }
$$

본 연구는 국토해양부 2009년도 해양중소 - 벤처기술개발 사업의 지원 (예산과제번호 PJT200293)으로 수행되었음.

\section{참고문헌}

Blois MS. 1958. Antioxidant determination by the use of a stable free radical. Nature 26, 1198.

Brown S and Diffey BL. 1986. The effect of applied thickness on sunscreen protection : in vivo and in vitro studies. Photochem. Photobiol 44, 509-513.

Cole C and VanFossen F. 1988. Rapid in vitro evaluation of sunscreens, SPF and PFA. Photochem. Photobiol 47, $73 \mathrm{~S}$.

Ha JH, Kim Y, Oh SH, Kim SS, Jeong MH, Lee HY and Jeong HS. 2009. Effects of Rubus coreanus extracts on ultraviolet-A irradiated cultured human skin fibroblasts. Korean J Medicinal Crop Sci 17, 321-327.

Kim EJ, Lee TH and Shin HJ. 2009. Extraction and isolation of antioxidant fraction from waste of grape products for cosmetic application. KSBB Journal 24, 477-482.

Kim KD. 2004. Research and application for natural extract that contain ultraviolet rays absorbent ingredient. J Soc Cosmet Scientists Korea 30, 117-122.

Kim KD, Lee YD, Park SS, Youn SH and Lee SH. 2000. The effect and stability of plant extract ingredient as uv absorber. J Soc Cosmet Scientists Korea 26, 41-58

Kim JA. 2004. Screening of crude drug extracts with UV protective and skin-lightning effects. Master Thesis, Catholic University of Daegu. 6-20.

Kim JH. 2009. A study on cultivation of Gracilaria chorda. Master Thesis, Chonnam National University. 1-6.

Kim YS and Koo JG. 2003. Seasonal and regional variations of agar yield and properties of tetrasporophytes and gametophytes in Korean Gracilaria verrucosa. J Kor Fish Soc 36, 474-479.

Lee HW. 2008. Dermatology. Park JT, ed. Kwangmoonkag, Seoul, Korea, 92-110.

Lee HB, Lee JO, Nguyeb Dung H, Yoon SA, Um JM, Lee YR, Moon HI, Chung JH and Kim EK. 2009. UVB protective effect of yeast originated selenium peptide on fibroblast. KSBB Journal 24, 463-468.

Ward LB. 1987. Human sunscreen evaluation protection from sunburn. Cosmetics and Triletries 102, 83-89

$\begin{array}{ll}\text { 2010년 } & \text { 5월 17일 접수 } \\ \text { 2010년 } & \text { 5월 25일 수정 } \\ \text { 2010년 } & \text { 6월 15일 수리 }\end{array}$

